\title{
Recreating Cities as Bodies of Power, Knowledge and Space
}

\author{
Anne Wagner ${ }^{1}$ \\ Published online: 18 June 2019 \\ (c) Springer Nature B.V. 2019
}

Any work on bodies requires a minimal knowledge of the general organization of cities, monuments, buildings and even their small devices. First of all we should consider the study of the shapes and structures of these bodies and their respective parts, as well as their relationships with each other. Then we will be in a better position for studying the functioning of the bodies, i.e. the way they play their roles and allow power to be maintained, regulated and/or forbidden.

We often employ many expressions pertaining to the domain of urban functioning, which call upon some human vital bio-components, such as the green lung of New York, the belly of Paris, urban arteries. This architecture of the city as a body is universal and corseted for Le Corbusier [8]. So, reterritorialization [2] plays a central role when, for instance, Le Corbusier radically modified after WWII the old conception of the city, being tortuous and chaotic, hazardous and clumsy, random and spontaneous. With his vision, he created blocks of bodies gathered together to ensure that as many citizens as possible could be accommodated in these new types of architecture. But even beyond this architectural vision, the elements that make up the city (parks, city centers, universities, city halls, court buildings, hospitals, benches, cameras, traffic lights, etc.) seem themselves to be the organs of a more complex and complete system. Man finally built the city as his own reflection, with some similarities and discrepancies that are sometimes highly visible:

We shape our dwellings and afterwards our dwellings shape us [1].

Shapes, buildings and devices can change people's behaviors, increasing and/or decreasing their sanity. Therefore new patterns of interactions have been created to adapt to History, to new ways of living, working or even recreation. But still, humans are the blood that flows through the veins of the city and makes it possible to feed, develop and grow bodies in a more or less autonomous, anarchic, free way. But this blood is sometimes imperfect, unhealthy, improper, dangerous, and toxic for the well-being of these bodies.

Anne Wagner

valwagnerfr@yahoo.com

1 Centre de Recherche Droits et Perspectives du Droit, équipe René Demogue, Lille University, Lille, France 
Cities as bodies are complex systems of organized societies such as social animals. The very existence of these bodies revolves around a highly structured organization as a whole. Communication, complex building construction, environmental control, defense, and division of the labor are just some of the behaviors that Man has developed to exist successfully in society, like the social colonies of bees. Furthermore, the wolf social structure is also fascinating too and connected to Man because they have a very strict level of hierarchy that has to be adhered to by all the members of the pack, which in theory minimizes power conflicts and lowers aggressive behaviors among them. Those who tend to escape this regulatory power are rejected from the structure, and become uncontrollable, autonomous parts outside the pack and its regulation mode. So just like a sick body, they must be disconnected from others to avoid any spread of the plague.

As a result of an undeniable evolution, bodies have largely changed over time. Indeed, dichotomy between healthy/ill bodies arises from these architectural forms and shapes, leading to issues of (in)salubrity, (ir)respect, psychological drama/black comedy [10], liberty/oppression, or space (mis)management. The duality in these types of bodies constitutes the Evil Twin, ready to collaborate with the other, but also willing to have the last word over the other in terms of (un)revitalized urban management. So, the triadic dimension of the dominance pattern can lead to permission, prohibition, or even subversion. Bodies can, therefore, reflect the greatest fears, but also the deepest desires of Man.

Besides, cities are subject to more or less harmful influences and are sometimes sick bodies, which may have been transformed and/or mutilated for the purposes of supervision, of outrageous connections: this is hyper-visibility in every sense of the word. This hyper-visibility of arteries allows a better and/or worse flow of data, and so generate a kind of living monster, an overpowering body, which beyond the power that human beings had conferred on it, will grant itself even more important rights (ref to the Kraken Theory). It could either be a liberticidal power that will generate ever-increasing neighborhood conflicts and lead to psychological, verbal and/or physical violence [9] or an information flow release (ref. to Octopus) without any real imposed supervision [9]. This body could then either become castrator or have a liberating power, in a given spatio-temporal space, causing flooding, temporary, or even permanent stoppage in the flow of communication, management and organization. Accordingly, and similar to what Kress and Leeuwen quoted in their grammar of visual design, there exists

a usable description of major compositional structures which have become estab-

lished in the course of the history of Western visual semiotics, and to analyse how they are used to produce meaning by contemporary image-makers [7: 1].

\section{Cities as Bodies of Power}

Any city is a patchy and heterogeneous body. It is a multi-dimensional living organism with spatial, demographic, cultural and political implications. Indeed a city is more a complex than a simple entity being the home to a multitude of other collaborative organisms. To model this mosaic of visions, we need to recreate cities as 
bodies of power. Foucault [3: 139] explains that a city is similar to a body, and so to a machine; in that:

its discipline, the optimization of its capabilities, the extortion of its forces, the parallel increase in its usefulness and its docility, its integration into systems of efficient and economic controls, all this was ensured by the procedures of power that characterized the disciplines: an anatomo-politics of the human.

Bodies can become connected to their surrounding environments to further develop congregations and social ties with their own essence: Human Beings. As such, people gathered in common communities that can be geographical, cultural, interestbased, and/or institutional. So the more communities they have in common, the greater the chance for them to encounter each other, and so to increase the probability of node connections between them. This interaction is of high importance because it is at the source of the generation of power. This generation is even higher when bodies and the people living in them are online connected. The online connection greatly facilitates networking, but still with some limits, or even deviances [9]. Cities become smarter with the advancement of technologies modifying interactions between people living within these bodies. As such the communication flow has evolved and modified their way of living and working, or even their understanding of each other. Hyper-connectivity can not only solve many issues but also create distance between people and more emotional interactions, because physical barriers have been removed [12]. This seems atypical since hyper-connectivity is supposed to further strengthen the links between the different elements of society without the Man, who is the instigator, having measured its full power, both positive and negative.

\section{Cities as Bodies of Space and Knowledge}

Space in Cities is therefore crucial because it enables to identify buildings, monuments and any other small elements by their symbolic load and power. Space influences the construction of collective and/or individual identities, and so to legitimize the exercise of power within these bodies. For instance, this is the case of surveillance where some cities around the world have removed physical walls to allow a natural observance of the surroundings [11]. Indeed cities evolve in order to meet the modern needs of the society, which implies: space, knowledge and power. Foucault [4: 246] gives his position on it when he considers the interconnectedness between these three elements:

It is somewhat arbitrary to try to dissociate the effective practice of freedom by people, the practice of social relations, and the spatial distributions in which they find themselves. If they are separated, they become impossible to understand.

This interconnectedness enables to find culturally grounded categories, which are at the basis of a system of values being influenced by specific spatiotemporal 
management. This is the time when bodies as cities rediscover their place, legitimacy, and performance. Indeed a symbolic space and its respective small elements (video, traffic lights, etc.) do not have the same meaning seen from nearby or from afar, from the inside or from the outside. So the power viewed by Foucault is far more complex, intricate and omnipresent in cities as bodies:

Power reaches into the very grain of individuals, touches their bodies and inserts itself into their actions and attitudes, their discourses, learning processes and everyday life [6: 39].

This is also what Foucault describes when he explains that architecture may become an "apparatus of knowledge" [5: 137] for creating and sustaining power relationships with the study of the Panopticon [5: 182].

\section{Cities as III Bodies in Movies}

The city and the vision that people have of it also appears more and more frequently in films and series, as if to show the phenomenon of transplantation that can take place between the real and the imaginary worlds [10]. But is the imagination so far from reality? Or is it the imagination that is inexorably moving away from reality to create even more tensions within current film productions? These phenomena of tension between reality and imagination are a unique source of inspiration for producers, (1) transplanting them as they stand, (2) modifying them to make the situation even more burdensome and prevalent, or (3) even bursting them to show how anarchy, paranoia and lack of respect between human beings can affect community life, and thus the city in general by presenting the city as a sick body for which the right remedies must be found to cure it.

The key driving force in their recreated scenarios is the myriads of ways in which power(s) can be exercised not only by the prime characters but also by the surrounding urban ill landscapes, with a play on their respective moody atmospheres [13: 7].

\section{Recreating Knowledge for Cities}

This special edition on cities as bodies, sometimes sick, sometimes wise, attempts to take stock of a multifaceted vision of the city as a perspective of a world in evolution, in the midst of demolition or of worry; that is, subject to all the hazards of social life and its positive and negative influences on it.

The various contributors, through their varied analyses and taking up the three essential axes, make it a very interesting and innovative transversal reading that can raise doubts about the possibility of curing the evils of our contemporary societies in the long term, but still leaving a door open to care adapted to its cure. 


\section{References}

1. Churchill Winston. 1943. Public speech in the house of commons on October 28, 1943. Retrieved from: https://api.parliament.uk/historic-hansard/commons/1943/oct/28/house-of-commons-rebui lding. Accessed 20 May 2019.

2. Deleuze, G., and F. Guattari. 1988. A thousand plateaus. Minneapolis: University of Minnesota Press.

3. Foucault, Michel. 1990. History of sexuality, vol. 1. New York: Vintage.

4. Foucault, Michel. 1984. Space, knowledge, and power. In The Foucault reader, ed. Paul Rabinow, 239-256. New York: Pantheon Books.

5. Foucault, Michel. 1995. Discipline and punish: The birth of the prison. New York: Vintage Books.

6. Foucault, Michel. 1972-1977. Power and knowledge. Edited by Colin Gordon. New York: Pantheon Books.

7. Kress, R.Gunther, and Theo Leeuwen. 2006. Reading images: The grammar of visual design. London: Routledge.

8. Le, Corbusier. 1964. La Ville radieuse: Éléments d'une Doctrine d'urbanisme pour l'équipement de la Civilisation Machiniste. Paris: Fréal.

9. Marusek, Sarah, and Wagner, Anne. 2019. “\#MeToo: A Tentacular movement of positionality and legal powers". International Journal of Legal Discourse 4(1): 1-14. https://doi.org/10.1515/ ijld-2019-2017.

10. Pile, Steve. 1996. The body and the city: Psychoanalysis, space and subjectivity. London: Routledge.

11. Wagner, Anne. 2011. French urban space management: A visual semiotic approach behind power and control. International Journal for the Semiotics of Law 24 (2): 227-242.

12. Wagner, Anne. 2019. E-victimization and E-predation theory as the dominant aggressive communication: The case of cyber bullying. Social Semiotics 29 (3): 303-318.

13. Wagner, Anne, and Cheng Le. 2019. Law, cinema, and the Ill City: Imagining justice and order in real and fictional cities. London: Routledge.

Publisher's Note Springer Nature remains neutral with regard to jurisdictional claims in published maps and institutional affiliations. 